\title{
THERMAL COMFORT STUDY OF TEACHERS' ROOM AT SEKOLAH BINA MULIA PONTIANAK
}

\author{
Albert Suryajaya'; Tri Wibowo Caesariadi ${ }^{2}$ \\ ${ }^{1}$ Student of department of Architecture, Tanjungpura University, Indonesia \\ ${ }^{2}$ Lecturer of department of Architecture, Tanjungpura University, Indonesia \\ musaparadisca@gmail.com
}

\begin{abstract}
Thermal comfort is one of the important aspects to ensure the comfort of a building. School building, e.g. Sekolah Bina Mulia, Pontianak is used for education activities for about eight hours a day. The teachers' room of Sekolah Bina Mulia is located on the fourth floor and still applies the natural air ventilation system while other rooms use mechanical ventilation system. It is interesting to see thermal comfort condition in the teachers' room. The thermal comfort of the room depends on the environment. Because of its position on the fourth floor, the wind circulation can flow freely and the application of air ventilation is possible. The average temperature is $29.599^{\circ} \mathrm{C}, 71.216 \%$ for relative humidity and $0.143 \mathrm{~m} / \mathrm{s}$ for wind speed, and $29.482^{\circ} \mathrm{C}$ for MRT. The average value of PMV is 1.615. The thermal comfort value, based on the average of PPS*(PMV) calculation for three days observation is 0.130 and it is the neutral condition. This means the room is comfort for the users and it is mainly because of the windows, sun shading, and the building materials which support the natural air ventilation of the school.
\end{abstract}

Keywords: Thermal comfort, natural air ventilation, tropic humid

\section{ABSTRACT}

Kenyamanan termal merupakan salah satu aspek penting untuk memastikan suatu bangunan dapat memberikan kenyamanan bagi penggunanya. Bangunan sekolah, seperti Sekolah Bina Mulia Pontianak merupakan bangunan pendidikan yang digunakan kurang lebih delapan jam dalam satu hari. Ruang guru pada sekolah Bina Mulia, yang terletak pada lantai empat masih menggunakan sistem ventilasi udara alami sementara ruangan lain menggunakan sistem penghawaan mekanikal. Kenyamanan termal pada ruangan tentu sangat tergantung pada Keadaan lingkungan. Karena posisinya yang cukup tinggi, pergerakan udara pada ruangan juga lebih bebas. Artinya, aplikasi ventilasi udara alami sangat memungkinkan. Nilai temperatur udara rata-rata pada ruangan adalah 29,599 ${ }^{\circ} \mathrm{C}$, kelembaban $71,216 \%$, kecepatan udara $0,143 \mathrm{~m} /$ det dan nilai temperatur radiasi $29,482^{\circ} \mathrm{C}$. Nilai PMV rata-rata pada ruangan adalah 1,615 . Nilai $\mathrm{PPS}^{*}(\mathrm{PMV})$ rata-rata pada ruangan tersebut dalam tiga hari pengamatan adalah 0,130 dan merupakan kondisi netral. Ini artinya ruangan tersebut nyaman bagi penggunanya, yang pada dasarnya dikarenakan sistem jendela, pelindung matahari, dan material bangunan dapat mendukung ventilasi udara alami pada bangunan.

Kata kunci: Kenyamanan termal, penghawaan alami, tropis lembab

\section{Introduction}

Schools are the place where students and teachers are doing educational process. In order to optimize the function of the school, it has to provide the human comfort of the building. Thermal comfort, as one of the comfort indicators, has important effect on the users activities on the school. If the thermal comfort, whether it is natural or mechanical system, is not supported by the school building, the users will feel that the room is not suitable for the educational activities.

The thermal comfort is effected by the environmental and human factor. The environmental factor consists of the air temperature, humidity, air circulation, and sun radiation. The human factor consists of clothes and human activity. (Satwiko, 2005) The natural air ventilation system is effected by the air circulation system, sun radiation, and the other environmental factors. The system will effect on the placement of the windows, sun shading, air ventilation, and room circulation. The building design will consider the room position, and how the building can adapt to the environment. Different from the natural air ventilation system, the mechanical air 
conditioning uses the electronic air conditioner as the air circulation source. The design will effect on the placement of the units, and the thermal condition can be easier to control and it will not depend on the weather. But, the mechanical air conditioning will consume a lot of energy, and it can produce the waste and electromagnetic radiation, which effects on human body.

This research focuses on Sekolah Bina Mulia, a private school in Pontianak. This school building's shape has the linear formation, which has the long-shaped building, and all the rooms faces the outdoor environment. The school was firstly designed for the natural air ventilation, with the application of the cross ventilation system for each rooms. Actually, if all rooms can face the outdoor environment, the air from the environment can flow into the room, and the room will require the sun shading to decrease the effect of the sun radiation. So, the shape of the school, and the window system for the building is ideal for the air circulation and sun radiation barrier.

The purpose of the research is to figure out the natural thermal condition quality of the teachers' room of Sekolah Bina Mulia, and to seek for the factors which effects the quality of the natural air ventilation system of the teachers' room. The objective is to find out the quality of the natural air ventilation, which causes the school applies the air conditioner in order to fulfill the thermal comfort of the school.

The scope of the research is the teachers' room 2 which is located on the fourth floor. The out-door air from the environment will flow stronger on the higher places than the lower places, so the fourth floor or fifth floor rooms is considered more comfort than the first, second, and the third floor. The rooms on the fifth floor have applied the mechanical air conditioning, while the teachers' room on the fourth floor does not. So, the teachers' room is representative for the natural air ventilation of the building, and because this room is important for the teachers' teaching preparations.

\section{Literature Review}

Based on the definition of International Standard Organizations (1984), Thermal comfort is generally defined as that condition of mind which expresses satisfaction with the thermal environment. Dissatisfaction may be caused by the body being too warm or cold as a whole, or by unwanted heating or cooling of a particular part of the body (local discomfort).

The International Standard iso 7730 1994 decides the PMV and PPD as the thermal comfort index. The Predicted Mean Vote (PMV) predicts the mean vote (with the ASHRAE seven-index scale) than a group of subjects with activities, clothing, and specified thermal environment. The Predicted Percentage Dissatisfied (PPD) predicts the percentage of the dissatisfied of the subject with activities, clothing, and specified thermal environment. (ASHRAE, 2001 in Orosa, 2009)

Fanger's PMV model is based on thermoregulation and heat balance theories. According to these theories, the human body employs physiological processes (e.g. sweating, shivering, regulating blood flow to the skin) in order to maintain a balance between the heat produced by metabolism and the heat lost from the body. In extreme thermal conditions, this regulation is necessary for the body to function properly. In office buildings, it is very unlikely that temperatures associated with serious body disfunction will occur, but thermoregulation is still used to maintain a comfortable heat balance (ASHRAE, 2001 in Orosa, 2009).

Furthermore, Orosa (2009) mentions that The ASHRAE Thermal Sensation Scale for PMV mentions the index of the PMV is : $-3=$ Cold, $-2=$ Cool, $-1=$ Slightly Cool, $0=$ Neutral, $1=$ Slightly warm, $2=$ warm, $3=$ hot. Fanger's PMV model combines four physical variables (air temperature, air velocity, mean radiant temperature, and relative humidity), and two personal variables (clothing insulation and activity level) into an index that can be used to predict the average thermal sensation of a large group of people in a space.

According to Brager and De Dear (2001), current thermal comfort standard and the models underpinning them purport to be equally applicable across all types of building, ventilation, occupancy pattern and climate zone. There also other factors which effects the thermal comfort, such as individual differences, building differences, outdoor climate, behavioral and psychological adaptation.

Furthermore, Brager and De Dear (2001) said that females are more sensitive than males, because females prefer the comfort temperature is usually $1 \stackrel{\circ}{-}$ warmer than males, beside the differences of the clothing and activities. Furthermore, every people have different behavioral and psychological adaptation each other. It means there is a relation between humanity feelings to the environmental comfort

According to Brager and De Dear (2001), the environment also effects on the thermal comfort, because in the neutral temperature for air-conditioned building differs to the natural air ventilated building. which are not controlled by the human itself. It is effected by the outdoor climate. The outdoor climate, makes people from different climates or seasons are comfort with a temperature, but that does not mean the other people are comfort with it too.

So, the PMV model which are said by Fanger is not the only aspects which effects on human thermal comfort. There are more factors which make the thermal comfort for a person is different with other person, as how every person always have differences each other. 
The normalization of individual thermal sensation votes for different values of mean vote distribution has obtained a mean of 0 and standard deviation of 1.125 . However, in this model, $80 \%$ satisfaction falls within the range of $-1.3<\mathrm{PMV}<+1.3$. The equation that represents this curve is given in equation:

$$
P P S *(P M V)=0.355 \times e^{-0.395 P M V 2}
$$

Normal distribution is a continuous probability distribution that has bell-shaped probability density function, known as the Gaussian function or as the bell curve, informally. A standard distribution will have mean equivalent to 0 whereas the variance is equivalent to 0 . The result obtained from the normal distribution of PPS is nonnormal distribution with variance greater than 1 even though the mean fall on 0 .

The differences of intersection at $80 \%$ PPS(PMV) and PPS*(PMV) is due to the quartic exponential function in PPS (PMV) . Based on adaptive hypothesis, people in warmer climatic zones prefer warmer indoor temperature than those in cold climatic zones. This means that their PMV will be located beyond the limit of $-1<$ PMV $<+1$. Besides, people living in extreme climate countries will have higher tolerance in towards indoor thermal environment (Wong et al., 2002; Nicol, 2004 in Pau et al., 2013). By transforming PPD (PMV) to PPS (PMV) and later normalize it to PPS* (PMV), the range of $P M V$ for $80 \%$ satisfaction has been widen to -1.3 to +1.3 .

According to Satwiko (2004), The thermal comfort for humid-tropical countries, such as Indonesia is when the temperature is about $24^{\circ} \mathrm{C}<\mathrm{T}<26^{\circ} \mathrm{C}$, with the relative humidity $40 \%<\mathrm{RH}<60 . \%$, and the wind velocity about $0,6 \mathrm{~m} / \mathrm{s}<\mathrm{V}<1,5 \mathrm{~m} / \mathrm{s}$. In fact the relative temperature of Indonesia is about $24{ }^{\circ} \mathrm{C}-32{ }^{\circ} \mathrm{C}$, and the relative humidity about $60 \%-95 \%$, and the wind speed is low on the morning and the night, but high in the day.

\section{Methodology}

The object of the research is Sekolah Bina Mulia, which is located in Jalan Abdurahman Saleh, Kelurahan Bangka Belitung Laut, Kecamatan Pontianak Tenggara, Pontianak, West Kalimantan. This school's site area is $5052 \mathrm{~m}^{2}$, and the building coverage area is $4811 \mathrm{~m}^{2}$. The main focus of the object is the natural air ventilation condition of Sekolah Bina Mulia.

The Scope of the research is the teachers' room in the fourth floor, which is on the same floor with the classrooms. The selection of the sample consider its position in higher place means the air pressure and velocity is larger and stronger than the lower level rooms. Mechanical air conditioning is not applied in this room which means this rooms is representative to the natural thermal condition of the school.

The fourth and fifth floor is located on the higher positions, and it is representative for the quality of the natural air ventilation of the school building. This is because if the rooms are comfort enough for the users, it means the building has applied the ideal natural air ventilation. The fifth floor is used for the classrooms which are applied with mechanical air conditioning while the teachers' room of the fourth floor does not apply the mechanical air conditioning.

The teachers room on the fourth floor is divided into three parts; the teachers room, vice principal 1's room and vice principal 2's room. The room is firstly designed for one room, but because of the requirements for vice principal rooms, the room is added with partition, which is made of multiplex, to divide the room into three parts. Each partition becomes a wall and there are windows, which is used for air circulation and lighting for the room. The teachers room is used for twelve teachers, but sometimes there are more, especially when other teachers come to the room to discuss with other teachers

The observation takes 3 days i.e. Tuesday, November 19, 2013; Monday, November 25, 2013; and Tuesday, November 26, 2013. These days are taken because of the possibility of the observation and the weather difference of the days. At the first day, the weather was sunny and calm, the second day was cloudy and gloomy, while the third day was gloomy and rain.

The research sample is divided into five spots ( $A, B, C, D$, and Outdoor), with different condition (Figure 1). The Position $A$ is the position of teachers, where the wind can flow through the outdoor window, directly to the table, and flow again to the window which faces the corridor. The Position B has the Vice principal room as the air flow barrier. The Position $C$ faces the outdoor window directly, and Position D has its own window. The Outdoor sampling is taken on the corridor which directly faces the outdoor area. The Position D is not observed on the second day and third day. This is because the room is not in use that day, due to the absence of the vice principal.

\section{Discussion}

The three days observation has shown that the temperature, wind speed, and the humidity did not reach the thermal comfort zone. The thermal comfort index can be determined by the PMV and PPS ${ }^{\star}(P M V)$ to figure out the thermal comfort, as long as the users can adapt to the environment. 


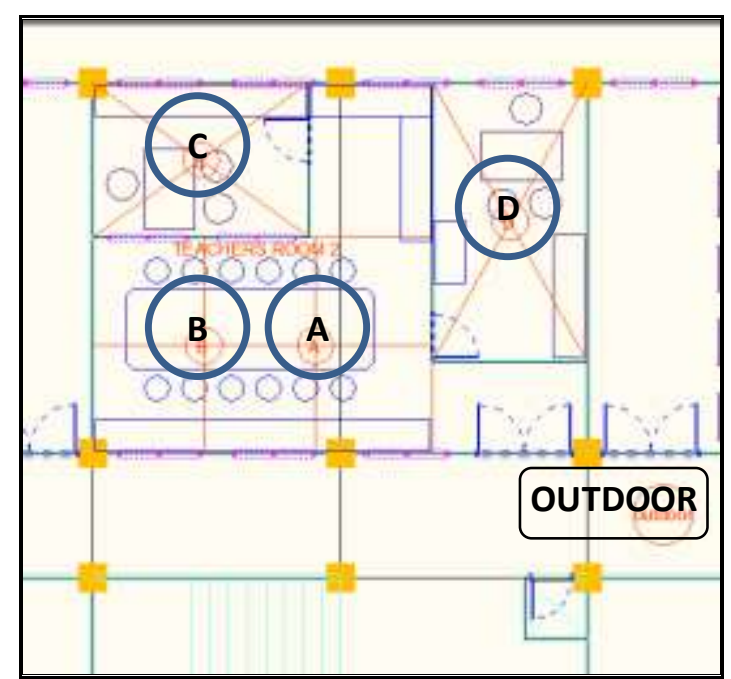

Figure 1 : Measurement points in teachers' room 2 in the fourth floor of Sekolah Bina Mulia Source : Author, 2013

Table 1 : Average Value of Indoor Thermal Condition on Three Days

\begin{tabular}{|c|c|c|c|c|}
\hline & Day 1 & Day 2 & Day 3 & Average \\
\hline $\mathbf{R H}(\%)$ & 61.96 & 74.43 & 77.26 & 71.22 \\
\hline $\mathbf{T}\left({ }^{\circ} \mathbf{C}\right)$ & 31.29 & 29.12 & 28.38 & 29.60 \\
\hline $\mathbf{v}(\mathbf{m} / \mathbf{s})$ & 0.14 & 0.14 & 0.16 & 0.14 \\
\hline $\mathbf{M R T}\left({ }^{\circ} \mathbf{C}\right)$ & 31.59 & 28.80 & 28.06 & 29.48 \\
\hline $\mathbf{C l o}$ & 0.57 & 0.57 & 0.57 & 0.57 \\
\hline Met & 63.80 & 63.80 & 63.80 & 63.80 \\
\hline PMV & 2.19 & 1.44 & 1.22 & 1.62 \\
\hline PPD & 83.53 & 48.37 & 36.83 & 56.24 \\
\hline PPS(PMV) & 16.46 & 51.63 & 27.15 & 31.75 \\
\hline PPS $^{*}(\mathbf{P M V )}$ & 0.05 & 0.15 & 0.19 & 0.13 \\
\hline
\end{tabular}

Source : Author, 2013

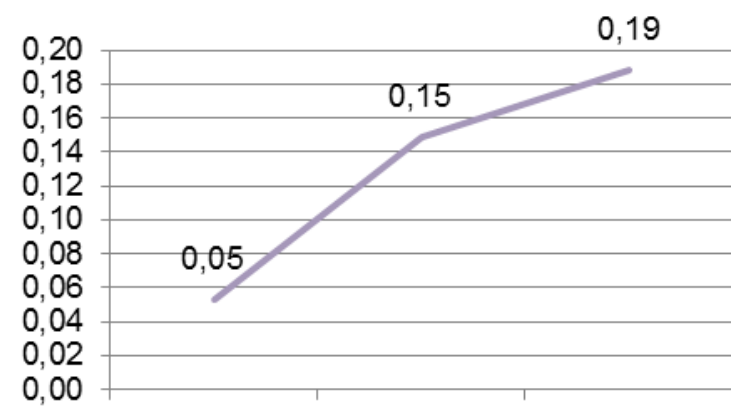

Day 1 Day 2 Day 3

Figure 2 : $\mathrm{PPS}^{*}(\mathrm{PMV})$ average value on three days observation Source : Author, 2013

From the result of these three days, the $\mathrm{PPS}^{*}(\mathrm{PMV})$ index shows that the teachers' room in Sekolah Bina Mulia is still comfort for the activities. Both on the sunny (Day 1) and cloudy (Day 2 and Day 3 ) days, the thermal comfort is still acceptable for the users. Through the observation of those three days, the value of the $\mathrm{PPS}^{*}(\mathrm{PMV})$ is near to neutral, which means the room is comfort enough.

The value of the PMV of the first day, is the highest, because the weather is sunny, which makes the condition is hotter than the other two days. For the cold climate people, the thermal condition of the teachers' room is hot, but for the tropical humid people, who have adapted the condition of the tropical environment, the condition is neutral, which can be seen on the $\mathrm{PPS}^{*}(\mathrm{PMV})$ value where the number is still close to 0.00 .

Different from the condition of the first day, the second day was cloudy with drizzling rain on the early of the morning. The thermal condition of the day was closer to the thermal comfort zone. This is the reason why the weather is cooler than the first day, and the PPS(PMV) index also higher than the first day. The PPS* $(P M V)$ index of the day is also near to neutral, which means that the condition is quite comfort for the users.

The condition of the third day has not much differences with the second day, because the weather was also cloudy with drizzling rain of the early of the morning. 
But, the PPS(PMV) index of the day is higher than the second day. This is because the thermal condition of the third day is a bit cooler than the second day, which makes the users feel that the room is comfort, and all of the respondents of the day also say that the condition is neutral, which means they deign to accept the thermal condition of the third day.

Actually, those three positions; $A, B$, and $C$ has slight differences for the value of its thermal comfort. This is effected by the different condition of those three positions. The Position A does not have any barrier for the air circulation from the outdoor area, which makes the air can flow freely, and the condition of the Position $A$ is more comfort than the other positions. The Position $B$ is near to the vice Principal room, which comes to be the barrier of the air circulation. The vice principal room wall has nako window (The window which consist of pieces of glass rotated for $90^{\circ}$ ) for the air circulation, but it does not opened, because the users do not want to harm themselves by the sharp edges of the nako window. The Position $C$ is close to the window, which makes the air flows directly through the window, but it is close to the sun shading, which makes the heat flows more on this position, after absorbed by the sun shading.

Table 2 : Thermal Condition Value Of Each Positions

\begin{tabular}{|c|c|c|c|c|c|}
\hline & A & B & C & $\begin{array}{c}\text { Aver- } \\
\text { age }\end{array}$ & $\begin{array}{c}\text { Outdoor } \\
\text { Condition }\end{array}$ \\
\hline $\mathbf{R H}(\%)$ & 71.74 & 71.11 & 70.74 & 71.20 & 70.39 \\
\hline $\mathbf{T}\left({ }^{\circ} \mathbf{C}\right)$ & 29.39 & 29.61 & 29.75 & 29.58 & 29.54 \\
\hline $\mathbf{V ~ ( m / s )}$ & 0.13 & 0.11 & 0.19 & 0.14 & 0.33 \\
\hline $\mathbf{M R T}\left({ }^{\circ} \mathbf{C}\right)$ & 29.34 & 29.62 & 29.40 & 29.45 & 29.43 \\
\hline Clo & 0.57 & 0.57 & 0.57 & 0.57 & 0.57 \\
\hline Met & 63.80 & 63.80 & 63.80 & 63.80 & 63.80 \\
\hline PMV & 1.57 & 1.66 & 1.58 & 1.61 & 1.48 \\
\hline PPD & 54.00 & 58.47 & 55.33 & 55.93 & 50.25 \\
\hline PPS(PMV) & 45.43 & 41.53 & 44.66 & 43.87 & 49.74 \\
\hline PPS ${ }^{*}(\mathbf{P M V )}$ & $\mathbf{0 . 1 3}$ & $\mathbf{0 . 1 3}$ & $\mathbf{0 . 1 3}$ & $\mathbf{0 . 1 3}$ & $\mathbf{0 . 1 5}$ \\
\hline \multicolumn{7}{|c}{ Source : Author, 2013 } \\
\hline
\end{tabular}

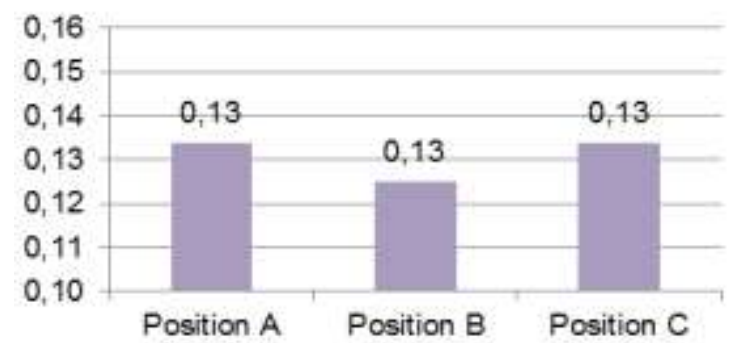

Figure 3 : PPS ${ }^{\star}(\mathrm{PMV})$ value of each position during three days observation Source : Author, 2013

The condition of those positions are almost similar. Even the outdoor condition also has close value to the indoor condition. This proves the indoor condition of the thermal comfort is similar to the outdoor condition. Actually, the room design has adapted the condition of the environment, which makes the application of the natural air ventilation is ideal for the building. The comparison of each positions of the indoor condition and the outdoor condition can be seen on the table below.

As seen in Table 2, it is obvious that the condition of every indoor positions have small differences. The Position B is a bit warmer than the other positions. This is caused by the air flow of this part. There is a vice principal room wall which comes to be the barrier for the air circulation. Because of it, the wind cannot flow as free as the other positions, which makes this position is a little bit hotter than the other positions. The Position $\mathrm{C}$ is also a bit hotter than Position $A$, because it is located closer to the window. The conduction of the heat, which comes from the heat absorption of the sun shading causes this position is a bit hotter than the other positions. Those aspects cause the small different of the thermal comfort condition, but surely the thermal condition is still neutral or comfort.

The position of the teachers' room provides the room with ideal natural air ventilation system. This is because the room is located in fourth floor. There is no other buildings on the side of the school. Because of this, the wind can flow directly to the building, and the wind speed is high, because in high positions, the wind is stronger. Furthermore, there is another room above the teachers' room. The heat from the radiation which absorbs during the day is not transmitted into the room directly because there is another room above, which protects the room to absorb the heat.

The thermal comfort is an important aspect for a building as it effects human feeling. If a room is comfort for the users, they can concentrate well to do their activities. The theory of thermal comfort mentions that the thermal comfort zone of tropical humid countries people is (Satwiko, 
2005):

- Relative humidity between $40 \%-60 \%$

- Wind speed between $0.6 \mathrm{~m} / \mathrm{s}-1.5 \mathrm{~m} / \mathrm{s}$

- Temperature between $24^{\circ} \mathrm{C}-26^{\circ} \mathrm{C}$

Table 3 : Average Value of Outdoor Thermal Condition on Three Days

\begin{tabular}{|c|r|r|r|r|}
\hline & Day 1 & Day 2 & Day 3 & $\begin{array}{c}\text { Aver- } \\
\text { age }\end{array}$ \\
\hline $\mathbf{R H}(\%)$ & 60.13 & 74.76 & 76.30 & 70.39 \\
\hline $\mathbf{T}\left({ }^{\circ} \mathbf{C}\right)$ & 30.98 & 28.66 & 28.98 & 29.54 \\
\hline $\mathbf{v ~ ( m / s )}$ & 0.53 & 0.23 & 0.24 & 0.33 \\
\hline MRT $\left({ }^{\circ} \mathbf{C}\right)$ & 31.00 & 29.11 & 28.17 & 29.43 \\
\hline Clo & 0.57 & 0.57 & 0.57 & 0.57 \\
\hline Met & 63.80 & 63.80 & 63.80 & 63.80 \\
\hline PMV & 1.88 & 1.30 & 1.25 & 1.48 \\
\hline PPD & 70.45 & 40.73 & 39.58 & 50.25 \\
\hline PPS(PMV) & 29.46 & 59.34 & 60.41 & 49.74 \\
\hline PPS $^{*}$ (PMV) & 0.09 & 0.17 & 0.18 & 0.15 \\
\hline
\end{tabular}

Source : Author, 2013

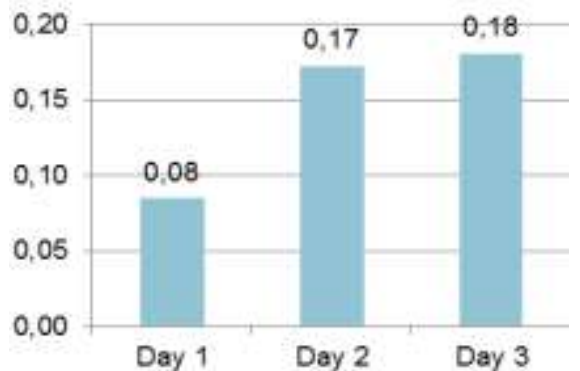

Figure 4 : PPS*(PMV) value of outdoor thermal conditon Source : Author, 2013

The value of the $\mathrm{RH}$ (relative humidity) of those three days are not on the value $40 \%$ to $60 \%$. The closest condition is only the Day 1, when the weather was sunny, and the humidity of the other two days are higher than $60 \%$. The temperature and wind speed values are also not on the value $24{ }^{\circ} \mathrm{C}-26^{\circ} \mathrm{C}$ and $0.6 \mathrm{~m} / \mathrm{s}-1.5 \mathrm{~m} / \mathrm{s}$. only the outdoor condition of the first day is a bit closer to $0.6 \mathrm{~m} / \mathrm{s}$. If the thermal comfort value is determined only by those aspects, the thermal condition of the school is never comfort, because even the environment cannot support the thermal comfort for a naturally air ventilated building.

Although the wind speed is usually less than 0.6, the humidity is more than $60 \%$, and the temperature is more than $26^{\circ} \mathrm{C}$, the room is still acceptable for the tropical humid people. The normal thermal condition of Pontianak, as the tropical humid area is $27.8^{\circ} \mathrm{C}$ for the temperature, $80.7 \%$ for relative humidity, 3 knots for the wind speed. This means the human adaptation has made the people can accept the thermal comfort, even it does not reach the index of the thermal comfort zone, which is accepted by the users for their daily activities. According to the $\mathrm{PPS}^{*}(\mathrm{PMV})$ value, the thermal condition is neutral, which means the users deign to accept the thermal condition. This is also supported by the opinion lists. Most of the respondents can accept the thermal condition, even though the thermal condition does not reach the thermal comfort zone value.

For the naturally air ventilated building, the thermal comfort is effected by the environment. The building have to adapt the environment because the weather is uncontrollable. The thermal comfort is effected by the components of building. Every components, such as windows, sun shading, materials, and the shape of the room effects on the thermal comfort. When a building directly faces the sun radiation without other buildings as a barrier, the building will absorb the heat easier, but the air circulation is better. But, if there is other building around the building which can be the barrier of the sun radiation, the air circulation cannot flow directly into a building.

The placement of rooms will effect on the air circulation. When there is another room as the barrier for the air circulation, the air will not flow directly to the room, which effects on the thermal comfort. So, the room placements must consider not only the accessibility, but also the thermal comfort of the room. Linear formation can make every rooms faces the outdoor area, but the sun radiation will give a great effect, because the façade will face the outdoor unit, which means that the window needs the sun shading in order to prevent the direct heat of the sun.

The window has the important role of the air circulation because the wind flow into the room through the window. The placements of the windows effects on the air circulation direction and the heat which 
flow into the room. the sunlight radiation will let the heat enter the room. So, the important aspects of the placements of window is the position and the sun shading, in order to not only make the ideal air circulation, but also to prevent the heat of the sun radiation enters the room.

Because of there is no other building beside the school building, the wind can flow directly from the environment to the room. On the fourth floor, the wind pressure is higher than the lower floors, this means that the wind speed on the fourth floor will also be higher than the other lower floors. But, the wind is unpredictable. Sometimes it does not blow, and sometimes it blows with high speed. The speed is usually 0.1 $\mathrm{m} / \mathrm{s}-0.4 \mathrm{~m} / \mathrm{s}$, but in some condition, it can reach $0.6 \mathrm{~m} / \mathrm{s}-1.3 \mathrm{~m} / \mathrm{s}$.

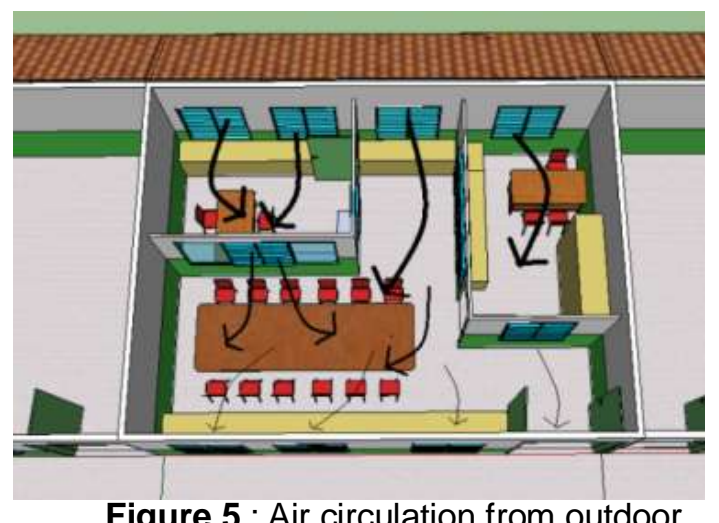

Figure 5 : Air circulation from outdoor Source : Author, 2013

The room, actually is comfort. This is because the room is supported with cross ventilation, which makes the air circulation from the outdoor unit can flow to the room. But, there is a vice principal room, which comes to be the barrier of the air circulation. There are nako windows which can be opened for the air circulation, but if the window is opened, the glass can harm the teachers on the other side, when there is someone who hit the glass. The space is too small for the teachers, because the distance of the table to the wall is only about 70 centimeters, and each teacher has distance about 30 centimeters, which causes they're too close each other, and there is small space for the air circulation, which makes the room is quite hot especially when it is crowded.

The fresh air circulation is important for a room. The air cannot flow freely to the Position $\mathrm{B}$, because the vice principal room is the barrier for the air circulation, and next to the room is a class and a corridor, and the corridor does not face the outdoor unit, which means that the air circulation cannot flow directly to the Position $B$, which makes the occupants in position $B$ feel sometimes they are not comfort when the room is crowded.

This means that the shape and room position has great effects for the thermal comfort. When there is a vice principal room in the side of other room, and some parts of the teachers room cannot face the outdoor area will effect on the air circulation. The air cannot flow well as long as it is not facing the outdoor environment. The window on the vice principal room is usually not used, because the teachers' space is narrow and the glass can harm anyone who hit the window while walking.

There is also air circulation from the corridor unit, but the air will flow into the other rooms except the teachers' room, because the wind always flow directly through the window, when the window is opened. But, because the classrooms have already applied the mechanical air conditioning, this means that the natural air ventilation is not used anymore for the school activities, and the fresh air can flow indirectly to the teachers' room because the wind diverse to other areas, after hitting the wall.

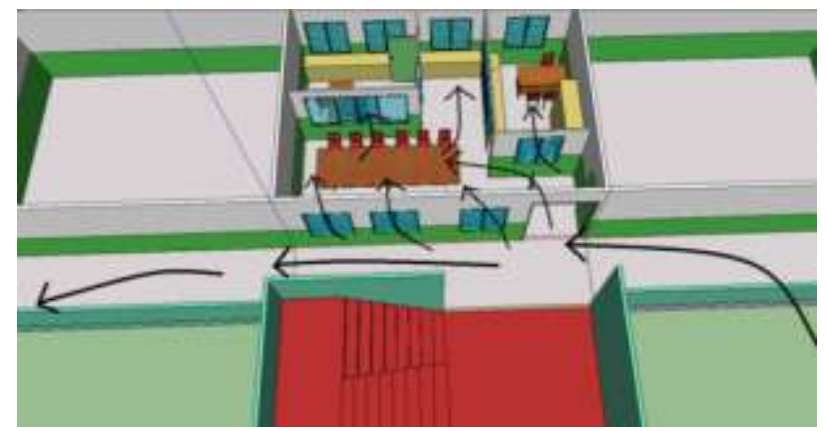

Figure 6 : Air circulation from corridor Source : Author, 2013 
The application of the sun shading of the room can prevent the direct sun radiation of the room. The angle and the width of the sun shading can protect the room for the direct sun radiation, which can flow directly to the room. This makes the room is protected from the direct heat of the sun. So, the areas which are near to the window will not get too much heat from the sun radiation. The sun shading is made of zinc, which makes the sun shading absorbs the heat of the sun radiation easily. After the zinc is overheated, the heat flow by conduction to the wall, and the heat from the wall flows by radiation into the room. So, this is the reason why the positions, which is nearer to the window is a little bit hotter, even though the air circulation flows directly through the window.

In this case, the sun shading can prevent the room from the direct sun radiation. But, the sun shading which is made of zinc will cause the increase of the room temperature, as long as the heat of the sun radiation, which is absorbed by the zinc, will flow into the room through the conduction. Even though the index of the radiation absorption of the zinc is low, but the conductivity is high. Because the placement of the zinc is near to the outer wall, the heat will flow into the room easier. The design of the sun shading is ideal for the room, because even on the most critical condition, the windows should be adequately protected from direct sun radiation.

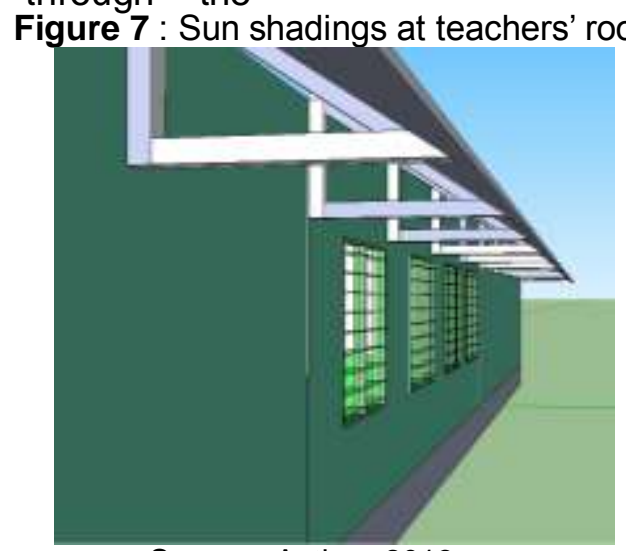

Source : Author, 2013

Number of users can effect on the thermal comfort, because living human has metabolism, and the metabolism will produce heat. When a room is crowded and not crowded, the thermal comfort index will be different. The teachers' room was not crowded which makes the room is still comfort enough for the users. But, most of the users say that the room is hot when the room is crowded. It means that in some period of time, the room is not comfort enough.

The room is usually crowded at the break time. The break time of the school schedule is twice a day and the break time has 20 minutes each. This means, the room is crowded for 40 minutes per day. The total activities of the school is 7 hours 25 minutes. This means that the room is not crowded for $91.01 \%$ of the school day activities and crowded for $8.98 \%$ of the total school day activities. This means that the thermal comfort of the room is still acceptable, as long as the room is not crowded, when the teachers are teaching and the room is only used for several persons.

Through the opinion lists, some respondents say that the room is comfort enough when it is not crowded. When the room is filled with a large number of people, the heat increases, because of the increase of the heat radiation from the human's body metabolism. So, the number of the occupations can increase the MRT (Mean Radiant Temperature) Value. It will effect on the room temperature and it is the reason why the respondents feel hotter when the room is crowded. The respondents admit that on the break time of the normal school operation, when all the teachers (twelve teachers) are on the same room, they feel that the room is hot. This means that during the normal condition, the PPS*(PMV) will have different result, because when the occupation changes, the temperature, mean radiant temperature, and air humidity will be higher, because of the human metabolism process and respiration, which makes the room get hotter and causes the room discomfort when it is crowded.

As a tropical humid country, Indonesia only has two seasons; the dry season and the rainy season. But, in Pontianak, the dry season and the rainy season is not easily predictable. The weather in Pontianak, as a tropical city, which is located directly in the equator line, is very hot, with the maximum heat of the day is around $32^{\circ} \mathrm{C}$.

As the result, Sekolah Bina Mulia, which is located on the middle of open areas, will be hot for several days, because there are no barrier of the school which means all the facades will absorb the heat. Because of this, the design of the room is important to provide the thermal comfort, because as a naturally ventilated building, the components of the building will give effect to the thermal comfort.

The weather has important role for a naturally air ventilated building. This is 
because the thermal condition depends on the outdoor condition. When the weather is hot, the rooms will also be hot, while if the weather is cool, the rooms will also be cool. For a naturally air ventilated building, the thermal condition is uncontrollable. The building only can control how the outdoor air can flow into the indoor areas, and how the heat of the sun radiation cannot make the room too hot. The room design has the most important role of the thermal comfort for a naturally air ventilated building.
The PPS*(PMV) value of the building shows the index is acceptable for the building. This means that the teachers' room of Sekolah Bina Mulia building has the ideal air circulation for the teachers' activities, especially when the room is not crowded. The respondents admit that the room is not comfort when the room is full. But, if the room is not full, the room comfort is still in neutral index even though the weather reaches the maximum or the minimum condition of Pontianak.

Table 4 : Maximum and Minimum Thermal Condition of Sekolah Bina Mulia Building

\begin{tabular}{|c|c|c|}
\hline & maximum & minimum \\
\hline RH (\%) & 99.5 & 53.6 \\
\hline Temperature $\left({ }^{\circ} \mathbf{C}\right)$ & 31.5 & 24 \\
\hline V (m/s) & 0.1 & 1 \\
\hline MRT ( $\left.{ }^{\circ} \mathbf{C}\right)$ & 31 & 27 \\
\hline W & 0 & 0 \\
\hline Clothing & 0.57 & 0.57 \\
\hline Metabolism & 63.8 & 63.8 \\
\hline PMV & 2.57 & -1.37 \\
\hline PPD & 94.8 & 44 \\
\hline PPS(PMV) & 5.22 & 56.08 \\
\hline PPS ${ }^{*}$ (PMV) & $\mathbf{0 . 0 2 5}$ & $\mathbf{0 . 1 6 0}$ \\
\hline Source : Author, 2013 \\
\end{tabular}

Actually, the teachers room of Sekolah Bina Mulia has been provided with windows, sun shading and building materials which make the room is comfort enough for the users. The temperature of the days which are taken as the sample is not too hot for the users, and the wind circulation was also free, as long as the room is supported by the weather and there was not many users on the room, which makes the room is comfort for the users. In different condition, the thermal comfort may be different, but in dominant occasion, the thermal comfort is good enough and acceptable for the users.

\section{Conclusion}

The thermal comfort value for teachers' room of Sekolah Bina Mulia has shown that the condition is neutral which means the users can accept the thermal comfort condition of the teachers' room. Although the thermal condition does not reach the thermal comfort zone, the users have adapted the condition of the environment, which makes the users deign to accept the thermal condition. Furthermore, the users of the room feel that the thermal condition is comfort during the days of the observation. The condition of the thermal comfort has concluded that the application of the natural air ventilation system for the teachers' room of Sekolah Bina Mulia is suitable.

The reason why the room is comfort for the users is because of the room design. The room is provided with cross ventilation system, which makes the air from the environment can flow into the room, spread, and causes the ideal air circulation. The windows are also provided with sun shadings, which protects the direct radiation from the sun to enter the room, so the heat flow of the sun radiation could be decreased. The condition of the indoor room is almost similar to the condition of the outdoor area. This means the design of the room has adapted the condition of the environment, and the room condition is comfort as long as the condition of the weather is also comfort for the users.

The design of the room also give slightly little difference of the thermal comfort condition for every positions. The part where the air can flow directly is better than if there is a wall, because there is a barrier for the wind circulation. The temperature of the part which is closer to the window is also a little bit hotter, because the heat from the sun radiation is absorbed by the sun shading, and the heat flows by the material conduction. Even though the thermal comfort value has small differences, these aspects are important considerations for room designs, because it can effect on the users' sense of the thermal comfort.

\section{Acknowledgement}

The writers would like to thank Mr. Zairin Zain as the course supervisor of this writing, Building Technology Laboratory of Department of Architecture at Tanjungpura University, teachers of Sekolah Bina Mulia who support and give the permissions of this research.

\section{Reference}


Alucci, Marcia Peinando; Leonardo Marques Monteiro. 2009. Thermal Comfort Index for The Assessment of Outdoor Urban Spaces in Subtropical Climates. University of Sao Paulo. Sao Paulo

Brager, G.S. and R. de Dear. 2001. Climate, Comfort, \& Natural Ventilation: A new adaptive comfort standard for ASHRAE Standard 55. University of California. Berkeley.

Charles, Kate E. 2003. Fanger's Thermal Comfort and Draught Models. Institute for Research in Construction. Ottawa

Darby, Sarah and Rebecca White. 2005. Thermal Comfort. University of Oxford. London

Hensen, J.L.M. 1990. Literature Review on Thermal Comfort in Tranisent Conditions. Eindhoven University of Technology. Eindhoven

Mangunwijaya, Yusuf Bilyarta. 1929. Pengantar Fisika Bangunan. Djambatan. Jakarta

Mors, Sanderter, Jan L. M. Hensen, Marcel
Loomans, Atze Boerstra. 2011. Adaptive thermal comfort in primary school classrooms: Creating and validating PMVbased comfort charts. Eindhoven University of Technology. Eindhoven

Orosa, Jose A. 2009. Research on the Origins of Thermal Comfort. University of A Coruña. A Coruña

Parsons, Ken. 2003. Human Thermal Environments: The effect of Hot, Modern, and Cold Environments on Human Health, Comfort, and Performance. Tj International Ltd. Cornwall

Pau, J.S., William K.S. Pao, Shaharin A. Sulaiman, and E. Halawa. 2013. Adaptive Thermal's Model for Optimum Thermal Comfort Setting fo Lecture Halls in Malaysia. CREAM - Current Research in Malaysia Vol.2, No. 2

Satwiko, Prasasto. 2005. Fisika Bangunan 1 Edisi 2. Andi. Yogyakarta. 